\title{
EVALUASI DAN PENETAPAN LAHAN PERTANIAN BERKELANJUTAN UNTUK PENCEGAHAN ALIH FUNGSI LAHAN DI KABUPATEN BANGLI
}

\author{
I Made Adnyana ${ }^{1 *}$, I Nyoman Puja, ${ }^{1)}$ I Dewa Made Arthagama ${ }^{1)}$ \\ ${ }^{1)}$ Program Studi Agroekoteknologi, Fakultas Pertanian Universitas Udayana \\ *Email : adnyanamade@gmail.com
}

\begin{abstract}
The research was done in the area of paddy soil in Bangli District, Bangli Regency to identification, evaluation, and mapping the paddy soil area that have to maintain as a sustainable agriculture. To achieve these objectives, the research conducted through several activities, namely: soil survey and environment, physical and chemistry of soil analysis, and mapping the model of the prevented exchangeable paddy soil functions. Depend on plan lay out space (called RTRW) of Bangli regency, there were two models of sustainable agriculture decision at district of Bangli, where in each model, land (Subak) mapping as subak everlasting, subak buffer, and Subak convertion. Subak convertion was have opportunity to changing function. Subak convertion of Model I as 158,68 ha (2011 - 2021) and Model II as 78,14 ha (2021 - 2031) respectively.
\end{abstract}

Keyword: sustainable agriculture, changing land function, land (subak) mapping

\section{PENDAHULUAN}

Pemerintah Republik Indonesia sudah menghasilkan Undang Undang Republik Indonesia Nomor 41 Tahun 2009, tentang Perlindungan Lahan Pertanian Berkelanjutan. Ruang lingkup perlindungan lahan pertanian mencakup perencanaan dan penetapan, pengembangan, penelitian, pemanfaatan, pembinaan, pengendalian, pengawasan, system informasi, pemberdayaan petani, pembiayaan, dan peran serta masyarakat. Dalam pasal 11 Undang Undang tersebut diamanatkan perencanaan lahan pertanian berkelanjutan disusun baik di tingkat nasional, provinsi, maupun kabupaten/kota; dengan tujuan untuk pencegahan alih fungsi lahan pertanian yang tidak terkontrol. Persyaratan minimum pembangunan berkelanjutan adalah terpeliharanya dengan baik segala sesuatu yang diberikan oleh alam (total natural capital stock) pada tingkat yang sama atau kalau bisa lebih tinggi dibandingkan dengan keadaan sekarang (Saragih, 2002; dan Thuc Son, and Quang Ha. 2002)

Kabupaten Bangli dengan luas wilayah 520,81 $\mathrm{km}^{2}$ atau 9,25\% dari luas wilayah Provinsi Bali memiliki lahan pertanian seluas 36.327 ha, terdiri atas lahan sawah 2.886 ha dan lahan bukan sawah 33.441 ha (Bangli Dalam Angka 2016 dan Pasedahan Agung, 2013). Lahan sawah Kabupaten Bangli tidak hanya penting untuk produksi padi dan ketahanan pangan, tetapi nilai-nilai budaya agrarisnya dan lahan dengan lansekap yang indah dan eksotik merupakan faktor yang sangat penting bagi perkembangan pariwisata dan sektor-sektor lainnya. Upaya mempertahankan integritas budaya dan lansekap fisik tentu bukan hal yang mudah karena pembangunan akan selalu membawa perubahan terhadap ekosistem (Reijntjes, at.al, 2006 ; Nguyen Van Bo, 2002; Adnyana, 2006, dan Adnyana, 2010)

Pembangunan pariwisata harus memperhatikan kelestarian lingkungan, karena perkembangan pariwisata menyebabkan kebutuhan keruangan untuk prasarana fisik dan aktifitas sosial budaya. Kecenderungan terlalu mengedepankan sektor favorit pariwisata telah terbukti diberbagai tempat lainnya sebagai akar penyebab terjadinya lingkungan yang tidak seimbang, keindahan dan estetika lingkungan terancam, dan pembangunan yang tidak berkelanjutan. Untuk itu, perlu dilakukan kajian penentuan dan penetapan lahan pertanian berkelanjutan untuk kelestarian lingkungan Kabupaten Bangli. Kegiatan ini sangat penting, karena berdasarkan hasil kajian yang akan dilakukan akan teridentifikasi dan dapat dipetakan lahan-lahan pertanian yang harus dipertahankan sebagai lahan pertanian berkelanjutan, tidak boleh dialihfungsikan dengan pertimbangan komprehensif mulai dari aspek geografis dan lokasinya strategis, sosial-ekonomi-budaya, potensi dan kesesuaian alam, estetika lingkungan, nice view, dan lain-lain.

\section{METODOLOGI}

\subsection{Survei Kondisi Sawah dan Lingkungan}

Penelitian dilakukan pada areal sawah yang tersebar di Kecamatan Bangli, Kabupaten Bangli, melalui metode survey yang dilakukan baik ke Dinas Pertanian, Perkebunan, dan Perhutanan, Bappeda 
Dan PM Kabupaten Bangli, maupun ke kelian subak. Pada setiap subak dikumpulkan informasi sebagai beriut : (1) kesesuaian lokasi sawah dengan RTRW, (2) penggunaan lahan, (3) posisi subak pada DAS dan satuan administrasinya, (4) air irigasi, (5) curah hujan, (6) bentuk wilayah, (7) elevasi, (8) kesesuaian lahan, (9) produktivitas lahan, (10) jarak subak dari pusat kota, (11) luas lahan, (11) view, dan (12) keberadaan tempat suci. Semua informasi tersebut diberi bobot, skor dan nilai sesuai metode strategi pengendalian alih fungsi lahan oleh Subadiyasa et al. (2013), yang telah dimodifikasi oleh penulis

\subsection{Analisis Karakterestik Tanah}

Pengambilan contoh tanah dilakukan di seluruh Subak yang tersebar di Kecamatan Bangli, Kabupaten Bangli. Tanah diambil pada lapisan olah sedalam $30 \mathrm{~cm}$, sehingga terkumpul 46 sampel. Contoh tanah dikering-udarakan, ditumbuk dan diayak dengan saringan $2 \mathrm{~mm}$, selanjutnya dianalisis karakterestik tanah seperti Tabel 1. Di samping itu dicatat pula data pendukung seperti : lereng, kedalaman efektif, singkapan batuan, curah hujan, kondisi banjir, dan teknik budidaya yang dilakukan petani. Selanjutnya, berdasarkan data tersebut, dilakukan evaluasi kesesuaian lahan, menggunakan metode oleh Puslittanak, Bogor (1997).

Tabel 1. Analisis Laboratorim Karakterestik Tanah

\begin{tabular}{lll}
\hline No & Macam Analisis & Metode \\
\hline 1 & Tekstur tanah & Pipet \\
2 & Kapasitas Tukar Kation (KTK) & Ekstrak $\mathrm{NH}_{4}$ Oac. $\mathrm{pH} 7$ \\
3 & Kejenuhan Basa & Ekstrak $\mathrm{NH}_{4}$ Oac. $\mathrm{pH} 7$ \\
4 & pH tanah & pH meter \\
5 & Salinitas Tanah & Conductometer \\
6 & N total & Kjeldhal \\
7 & P tersedia & Bray 1 \\
8 & K tersedia & Bray 1 \\
9 & C organik & Black and Walkley \\
\hline
\end{tabular}

\subsection{Pemetaan model alih fungsi lahan pertanian}

Langkah-langkah pemodelan :

1. Penyiapan Software QGIS 2.10.01 dan ArcGis 10.3, Data Citra Quickbird Tahun 2013 Kabupaten Bangli Liputan Tahun 2012 yang telah di Orthoretrifikasi.

2. Penyiapan Data-data Spasial per parameter dengan format shp, kemudian di registrasi dan disamakan system proyeksi koordinatnya menjadi UTM WGS $50 \mathrm{~s}$.

3. Setelah itu masing-masing data parameter digitas ditambahkan kolom keterangan, skor, dan nilai, kemudian diisi sesuai dengan data skoring parameter.

4. Melakukan proses Geoprcesing (overlay) dengan jenis Intersect seluruh data spasial parameter.

5. Kemudian hasil overlay di tambahkan kolom skor total dan dihitung total dalin keseluruhan nilai parameter.

6. Database hasil overlay dipindahkan kedalam excel, kemudian dilakukan pencarian Ring Populasi untuk mengetahui kelompok sebaran data hasil overlay digital.

7. Kemudian dari skor total dilakukan proses klasifikasi (pemodelan) dengan mencari data ratarata, jumlah data hasil overlay digital, standar deviasi. Klasifikasi dilakukan dengan beberapa pemodelan dari data rata-rata dan standar deviasi.

8. Kemudian data -data klasifikasi di input kedalam database digital untuk dilakukan klasifikasi spasial di Qgis. Dan didapatkan Batas-batas Zonasi Subak dalam beberapa pemodelan.

9. Setelah itu dilakukan pengukuran luas untuk mendapatkan luas subak lestari, penyangga, dan terkonversi dari setiap pemodelan zonasi sawah.

10. Proses kartografi (layout) peta-peta (11 Peta Parameter +4 Peta Pemodelan).

\section{HASIL DAN PEMBAHASAN}

\subsection{Model Penetapan lahan Pertanian Berkelanjutan}

Kabupaten Bangli memiliki RTRW yang berlaku mulai tahun 2011 dan berakhir pada tahun 2031 . Model penetapan lahan pertanian berkelanjutan disusun selama periode berlakunya RTRW. Model I berlaku mulai tahun 2011 sampai 2021 yang terdiri dari luas Subak Lestari $=115,53$ ha; luas Subak Penyangga $=361,40$ ha; dan luas Subak Terkonversi $=158,68$ ha. Model II berlaku mulai 2021 sampai 2031, yang terdiri dari luas Subak Lestari $=412,35$ ha; luas Subak Penyangga $=145,13 \mathrm{ha}$; dan luas Subak Terkonversi $=78,14$ ha. Data selengkapnya disajikan pada Gambar 1 dan Gambar 2

Berdasarkan citra satelit, luas lahan sawah di Kecamatan Bangli, Kabupaten Bangli adalah 635,58 ha; sedangkan menurut RTRW, sawah yang berada di zone pertanian adalah 458,89 ha, sawah di luar zone pertanian adalah 176,66 ha, dan non sawah di zone pertanian adalah 137, 99 ha. Sebaiknya alih fungsi lahan dilakukan pada areal sawah diluar zone pertanian atau areal non sawah, sesuai aturan perundangan yang berlaku, serta sebaran dan luasnya di masing masing desa bervariasi (Tabel 2). 


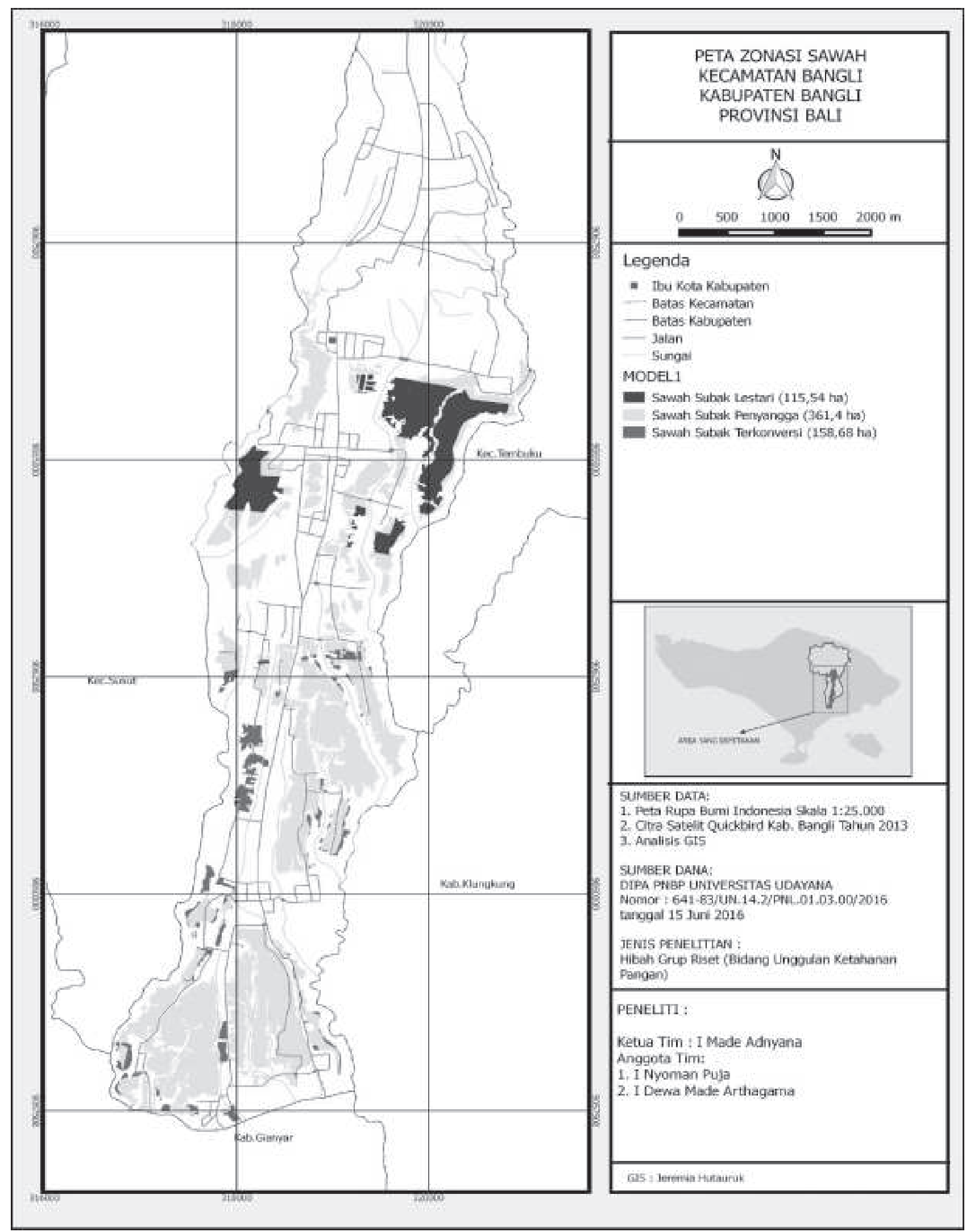

Gambar 1. Fungsi lahan, Model I 


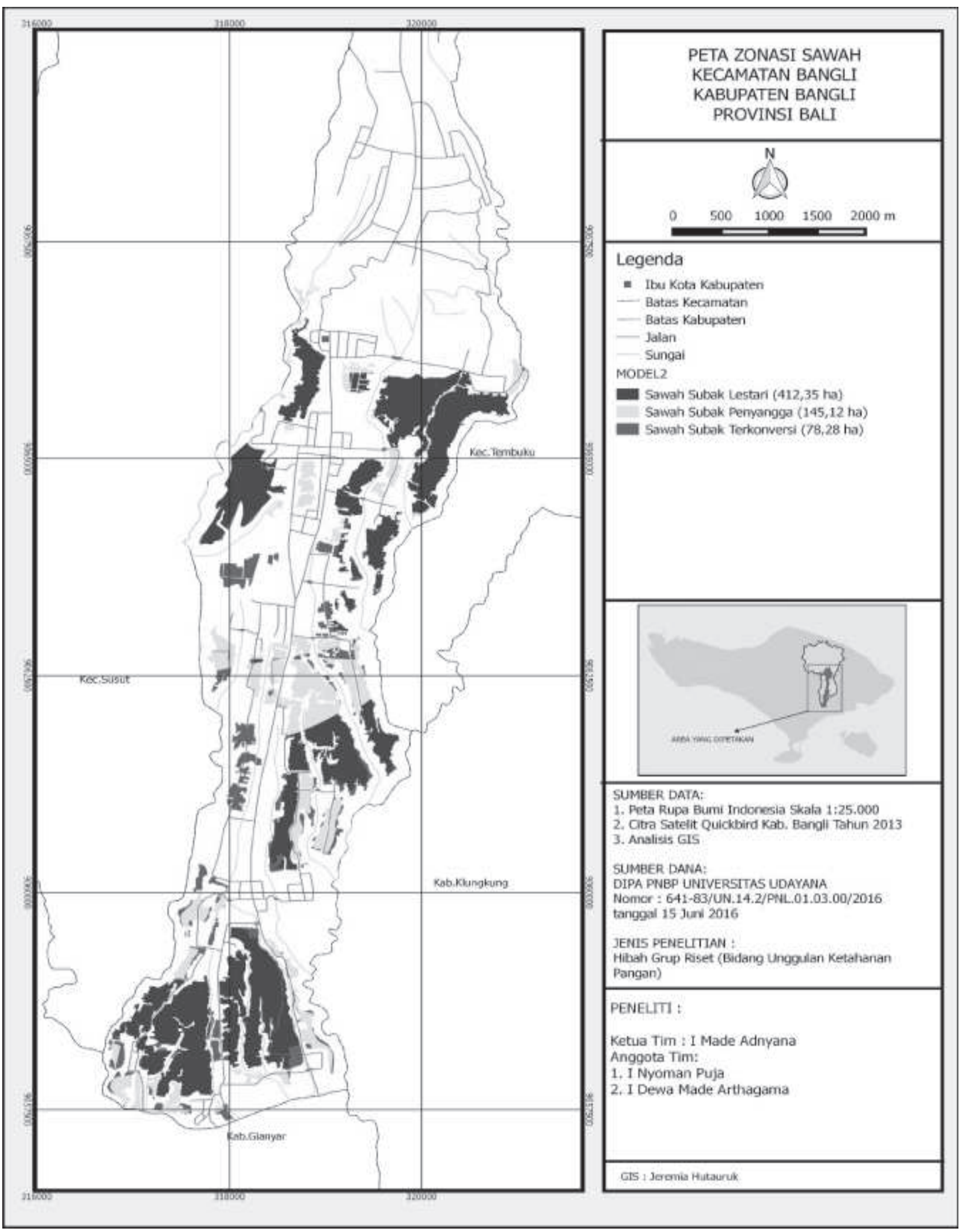

Gambar 2. Fungsi Lahan, Model II 
Tabel 2. Sebaran dan luas sawah terkonversi (alih fungsi) di Kecamatan Bangli, Kabupaten Bangli

\begin{tabular}{|c|c|c|c|c|c|c|c|c|}
\hline \multirow{2}{*}{ No } & \multirow{2}{*}{ Desa } & \multirow{2}{*}{ Luas Sawah (ha) } & \multicolumn{3}{|c|}{ Model 1 (ha) } & \multicolumn{3}{|c|}{ Model 2 (ha) } \\
\hline & & & Lestari & Penyangga & Terkonversi & Lestari & Penyangga & Terkonversi \\
\hline 1 & Bunutin & 110.97 & 0 & 100.56 & 10.41 & 78.40 & 18.87 & 13.70 \\
\hline 2 & Taman Bali & 158.63 & 0 & 142.40 & 16.23 & 95.17 & 38.82 & 24.77 \\
\hline 3 & Bebalang & 132.89 & 0.85 & 0 & 132.04 & 49.97 & 62.38 & 20.54 \\
\hline 4 & Kawan & 107.41 & 35.82 & 71.59 & 0 & 73.79 & 14.35 & 19.27 \\
\hline \multirow[t]{2}{*}{5} & Cempaga & 125.72 & 78.87 & 46.85 & 0 & 115.02 & 10.70 & 0 \\
\hline & Total & 635.62 & 115.54 & 361.4 & 158.68 & 412.35 & 145.12 & 78.28 \\
\hline
\end{tabular}

\section{SIMPULAN DAN SARAN}

\subsection{Simpulan}

Terkait dengan masa berlakunya RTRW Kabupaten Bangli, terdapat dua model penetapan lahan pertanian berkelanjutan di Kecamatan Bangli, Kabupaten Bangli, dimana pada masing masing model, lahan (subak) dirinci sebagai subak lestari, subak penyangga, dan subak terkonversi. Lahan pertanian (subak) terkonversi adalah lahan yang mempunyai peluang untuk beralih fungsi. Pada model I (2011- 2021), lahan terkonversi adalah 158,68 ha, sedangkan model II, lahan terkonversi menjadi 78,14 ha (2021- 2031).

\subsection{Saran}

Penetapan lahan pertanian berkelanjutan hendaknya dilakukan pada lahan pertanian lestari, sedangakan alih fungsi lahan pertanian ke non pertanian sebaiknya diprioritaskan pada lahan pertanian terkonversi

\section{DAFTAR PUSTAKA}

Adnyana, I.M. 2006. Teknologi Zone Agroekologi dalam Pembangunan Pertanian Berwawasan Lingkungan. Jurnal lingkungan hidup. Bumi Lestari. (6) : 1. Pusat Penelitian Lingkungan Hidup Lembaga Penelitian Universitas Udayana, Denpasar

Adnyana, I.M. 2010.Peningkatan kualitas tanah dalam mewujudkan produktivitas lahan pertanian secara berkelanjutan.Bumi Lestari. (11) : 1. Pusat Penelitian Lingkungan Hidup
Lembaga Penelitian Universitas Udayana, Denpasar

Nguyen Van Bo. 2002. The role of fertilizer in modern agriculture production in Vietnam. P 1-9. http:/ /www.fadinap.org/vietnam/fertilizer.html

Kabupaten Bangli Dalam Angka 2016. Badan Pusat Statistik Kabupaten Bangli

Pasedahan Agung. 2013. Data Subak/Subak Abian di Kabupaten Bangli. Dinas Pendapatan/ Pasedahan Agung Kabupaten Bangli

Reijntjes, C.; B. Haverkort and A. Water Bayer. 2006. Farming for the future. An Introduction to low-external-input and sustainable agriculture. The MacMillan Press Ltd, London. Cetakan ke 8, edisi Indonesia oleh Kanisius

Saragih, B. 2002. Kebijakan Pemberdayaan Lahan Kering untuk Mendukung Pembangunan Pertanian Berkelanjutan.Lokakarya Kurikulum Inti Facultas Pertanian se Indonesia. Mataram, 26-28 Mei 2002.

Thuc Son, and Quang Ha. 2002. Some feature of fertilizer need and fertilizer production in Vietnam. http://www.fadinap.org/vietnam/ fertilizer.html

Subadiyasa, N.N; I.Lanya; dan K. Sardiana. 2010. Strategi pengendalian alih fungsi lahan subak berbasis masyarakat dan upaya peningkatan produktivitas lahan di kabupaten Tabanan, Bali. Laporan penelitian. Universitas Udayana

Winarno, S. 2005. Kesuburan tanah. Dasar-dasar kesehatan tanah dan kualitas tanah. Gava Media, Yogjakarta 